\title{
БИОЛОГИЧЕСКАЯ АКТИВНОСТЬ ГУМИНОВЫХ ВЕЩЕСТВ САПРОПЕЛЯ РЕКИ УПЫ ТУЛЬСКОЙ ОБЛАСТИ
}

\author{
() Е.Д. Дмитриева", К.В. Сюндюкова, Е.В. Акатова, М.М. Леонтьева, Е.М. Волкова, Е.Н. Музафаров \\ Тульский государственный университет, пр. Ленина, 92, Тула, 300012 \\ (Россия), e-mail: dmitrieva_ed@rambler.ru
}

\begin{abstract}
Рассмотрено влияние природных полимеров - гуминовых веществ сапропеля реки Упы Тульской области на рост и развитие томатов F1 сорта Джина агрофирмы «АЭЛИТА». В составе гуминовых веществ установлено содержание основных функциональных групп (карбоксильные, фенольные и хиноидные), которые определяют их биологическое действие. Доказана обогащенность хиноидными группами, которые обладают окислительно-восстановительными свойствами, являются «ловушками» для активного радикала и влияют на функционирование антиоксидантной системы защиты в клетках растений. Выявлен стимулирующий эффект анализируемых гуминовых препаратов на рост экспериментальных растений: увеличение общей биомассы, биометрических показателей (длина и ширина листа, высота растений), повышение количества фотосинтетических пигментов, белка и аскорбиновой кислоты. Растения, получавшие в качестве подкормки гуминовые вещества сапропеля, отличались большим содержанием фотосинтетических пигментов, таких как хлорофилл $a$ хлорофилл $b$ и каротиноиды (на 58-69\%), аскорбиновой кислоты (на 104\%) и белка (на $60 \%$ ), по сравнению с контрольной группой. Гуминовые вещества содержат весь набор органических и неорганических веществ, необходимых для выращивания растений томатов. кислота.

Ключевые слова: гуминовые вещества, биологическая активность, фотосинтетические пигменты, аскорбиновая

Работа выполнена в рамках государственного задания №5.241.2014/К.
\end{abstract}

\section{Введение}

Гуминовые вещества (ГВ) - высокомолекулярные органические соединения, устойчивые к биодеструкции, образующиеся при разложении растительных и животных остатков под действием микроорганизмов и абиотических факторов среды, они входят в состав органической части каустобиолитов (углей, торфов, сапропелей) [1, 2]. В структуру ГВ входят алифатические соединения (сложные эфиры, сахара, аминокислоты) и ароматические фрагменты (лигнин и его производные), они имеют амфифильный характер из-за присутствия гидрофильных и гидрофобных фрагментов. В результате чего ГВ могут образовывать мицеллы при концентрации мицеллообразования выше критической (ККМ) [3, 4]. В почвенных условиях такие поверхностные

Дмитриева Елена Дмитриевна - кандидат химических наук, доцент кафедры химии, e-mail: dmitrieva_ed@rambler.ru

Сюндюкова Кристина Викторовна - аспирант, e-mail: kristina-syundyukova@yandex.ru

Акатова Екатерина Валентиновна - кандидат биологических наук, доцент кафедры биотехнологии, e-mail: katiaakatova@gmail.com

Леонтьева Мария Михайловна - магистрант, e-mail: senara07@gmail.com

Волкова Елена Михайловна - кандидат биологических наук, доцент кафедры биологии, e-mail: convallaria@mail.ru

Музафаров Евгений Назибович - доктор биологических наук, профессор, заведующий кафедрой биологии, e-mail: muzafarov.44@mail.ru действия ГВ играют важную роль в транспорте, биодоступности и способности ГВ к биологическому разложению [5].

Гуминовые вещества являются аккумуляторами органического и неорганического вещества почвы, они обогащены пигментами, витаминами, стеринами, каротиноидами биологически активными веществами и элементами для минерального питания растений (азот, фосфор, калий), а также микроэлементами (железо, цинк, медь, марганец, бор, молибден и т. д.) $[1,6,7]$.

Экспериментально установлено стимулирующее действие гуминовых веществ на рост и раз-

\footnotetext{
* Автор, с которым следует вести переписку.
} 
витие растений, повышение их устойчивости к неблагоприятным факторам окружающей среды (засуха, переувлажнение), стимулирование прорастания семян, повышение продуктивности крупного рогатого скота и птицы [8].

Будучи активными при низких дозах, гуминовые вещества применяют в растениеводстве как биостимуляторы роста растений и в качестве микроудобрения. Они представляют собой альтернативное решение для улучшения качества урожая и увеличения продовольствия. При использовании ГВ улучшаются буферные и ионообменные свойства почвы, транслокация и усвоение питательных веществ растениями.

Удобрения на основе гуматов калия и/или натрия с добавкой микро- ( $\mathrm{Mn}, \mathrm{Mo}, \mathrm{Co}, \mathrm{Cu}, \mathrm{Zn}, \mathrm{B})$ и макроэлементов (P, Mg, Fe) являются перспективными препаратами, особенно для карбонатных почв, где, несмотря на высокие концентрации микроэлементов, содержание их в доступной для растений форме невелико. Но чаще для этих целей применяют микроудобрения на основе синтетических лигандов (ЭДТА, ДТПА, ЭДДГА). Они эффективны, но в их промышленном производстве используют монохлоруксусную кислоту и этилендиамин, получаемые из хлорированных углеводородов. Подобное производство небезопасно для человека и окружающей среды. Кроме того, если регулярно вносить удобрения с синтетическими лигандами, то они накапливаются в почве, что приводит к ухудшению ее свойств. Поэтому создание и использование удобрений на основе гуминовых препаратов - куда более безопасная альтернатива [9].

Цель работы - определение влияния гуминовых веществ сапропеля реки Упы Тульской области на рост и развитие растений, и получение на их основе биологически активных препаратов - стимуляторов роста.

\section{Экспериментальная часть}

Для установления взаимосвязи между функциональным составом гуминовых веществ сапропеля и их биологической активностью на рост и развитие растений, в анализируемых препаратах исследовали основные функциональные группы и биологическую активность (всхожесть семян, биометрические параметры растений, содержание фотосинтетических пигментов, аскорбиновой кислоты и белка в зеленых частях растений).

Объектом исследования является сапропель (Тульская область, Тула, Зареченский район, река Упа) серого цвета. Река Упа берет начало на Воловском плато в трех километрах севернее поселка Волово, течет в пределах Среднерусской возвышенности, образуя большие петли. До Тулы преимущественное направление - на север, затем река поворачивает на запад. Общая длина реки 345 км. По берегам Упы распространена луговая растительность, основу которой составляют злаковые, бобовые, осоки, тысячелистник, клевер горный. Прибрежная зона реки покрыта тростником, кувшинками, рдестом, элодеем, на поверхности в большом количестве растет ряска.

Сапропель был сформирован на дне реки и состоит из опада древесных пород, травы, водорослей, обнаружены следы животных останков, мхов, грибного мицелия. Отбор пробы сапропеля производился в октябре 2015 г. Отбиралось по 6 образцов сапропеля на площади 3 м², после чего образцы усредняли.

Bыделение гуминовых веществ. К навеске образца из предварительно декальценированного сапропеля $10 \% \mathrm{HCl}$, добавляли 0,1 н раствор $\mathrm{NaOH}$ (соотношение сапропель: щелочь - $1: 6$ ), смесь кипятили в течение 2 ч при постоянном перемешивании и оставляли на 24 ч. Отстоявшуюся смесь фильтровали на складчатом фильтре. К фильтрату приливали $10 \%$ раствор $\mathrm{HCl}$ до $\mathrm{pH}=2$ (кислотность раствора определяли по лакмусовой бумаге). Полученный раствор фильтровали. Осадок (ГВ) сушили на воздухе. Очистку ГВ производили двукратным переосаждением из раствора и последующим диализом. Диализ проводили в мембранных мешках с размером пор 12-14 кДа. Длительность диализа - 24 ч [10].

Функииональный анализ гуминовых веществ. Количественное определение основных функциональных групп (карбоксильные, фенольные гидроксилы и хиноидные) проводили методом потенциометрического титрования. Общую кислотность ГВ (-COOH+ArOH) определяли баритовым методом, карбоксильные группы (-СООН) - Са-ацетатным методом со стеклянным и хлоридсеребряным электродами. Фенольные гидроксилы $(\mathrm{ArOH})$ определяли по разности между общей кислотностью и Са-ацетатным методом [11]. Для определения содержания хиноидных групп к навеске ГВ (0,0500 г) добавляли 5 мл 0,1 н раствора $\mathrm{SnCl}_{2}$ в 10 н $\mathrm{NaOH}$ и 10 мл 1 н $\mathrm{NaOH}$ (в качестве среды). Смесь перемешивали и оттитровывали водный слой $0,1 \mathrm{H}$ раствором $\mathrm{K}_{2} \mathrm{Cr}_{2} \mathrm{O}_{7}$ с платиновым и хлоридсеребряным электродами.

Биологическая активность гуминовых веществ исследовали на томатах F1 сорта Джина агрофирмы «АЭЛИТА». Для эксперимента была выбрана почва марки «Фасад», в состав которой входят верховой 
торф, биогумас, аглоперит, минеральные удобрения: содержание азота - не менее 150 мг/л, калий 300 мг/л, фосфор - 270 мг/л, $\mathrm{pH}=6,5 \pm 0,5$. Перед посадкой семена томатов и почву подвергали стерилизации. Семена погружали в $10 \%$ раствор $\mathrm{NaClO}$ с последующей промывкой в дистиллированной воде. Для снижения влияния микрофлоры почв на рост растений почвы стерилизовали в паровом стерилизаторе ВК75-01 течение 45 мин $\left(\mathrm{p}=1\right.$ атм, $\left.\mathrm{t}=100^{\circ} \mathrm{C}\right)$. Семена томатов высеивали в ящики по 20 штук в предварительно подготовленную почву, накрывали пленкой, создавая тем самым условия парника, и помещали под лампу дневного света.

Контрольной группой служили растения, посаженные в почву марки «Фасад». Они получали подкормку универсальным органо-минеральным удобрением «Идеал» один раз в 7 дней. В состав удобрения входили доступные для растений формы азота $\left(\mathrm{NH}_{4}{ }^{+}, \mathrm{NO}_{3}{ }^{-}\right)-5$ г/л, фосфор $\left(\mathrm{P}_{2} \mathrm{O}_{5}\right)-10$ г/л, калий $\left(\mathrm{K}_{2} \mathrm{O}\right)-$ 10 г/л, гуминовые вещества -2 г/л, $\mathrm{pH}=9 \pm 1$.

Рабочий раствор для подкормки экспериментальной группы растений с $\mathrm{pH}=7$ готовили растворением навески гуминовых веществ сапропеля в $0,05 \mathrm{H}$ растворе $\mathrm{NaOH}$. Полученный концентрат, так же, как и универсальное удобрение «Идеал», в количестве 10 мл растворяли в 1 л дистиллированной воды.

Биологическую активность гуминовых веществ оценивали по следующим показателям: всхожесть семян, биометрические параметры растений, содержание фотосинтетических пигментов, аскорбиновой кислоты и белка в зеленых частях растений.

Биометрические параметры определяли один раз в 7 дней. Они включали в себя замер длины стебля, длины и ширины настоящего листа, время начала цветения. Биохимический анализ растений (содержание фотосинтетических пигментов, аскорбиновой кислоты и белка в зеленых частях растений) проводили через 85 дней после начала эксперимента. Результаты экспериментов получены при многократных параллельных измерениях и обработаны методом математической статистики.

Содержание фотосинтетических пигментов анализировали спектрофотометрическим методом. Навеску 100 мг свежих листьев истирали в фарфоровой ступке, заливали 15 мл 96\% этанола, отфильтровывали в мерные колбы на 25 мл, раствор доводили до метки 96\% этанолом. Содержание фотосинтетических пигментов в вытяжке проводили в стеклянных кюветах, толщиной 1 см на фотоэлектрокалориметре в трехкратной повторности. Оптическую плотность раствора (А) снимали при следующих значениях длин волн: 470,649 и 665 нм [12, 13].

Содержание пигментов рассчитывали по следующим формулам:

Хлорофилл $a$ :

$$
C=13,95 \cdot A_{665}-6,88 \cdot A_{649}
$$

Хлорофилл 8 :

$$
C=24,96 \cdot A_{649}-7,32 \cdot A_{665}
$$

Каротиноиды:

$$
C=\frac{1000 \cdot A_{470}-2,05 \cdot A_{665}-114,8 \cdot A_{649}}{245} ;
$$

Содержание пигментов на 1 г сырой массы рассчитывали по формуле

$$
F=\frac{C \cdot V}{1000 \cdot m}
$$

где $F$ - масса пигмента, мг/г; $C$ - концентрация пигмента, мг/л; $V$ - объем вытяжки, мл; $m$ - масса навески листьев, мг [13].

Содержание аскорбиновой кислоты определяли йодометрическим методом. Навеску листьев $(2,00$ г) растирали в фарфоровой ступке в присутствии 15 мл $2 \%$ соляной кислоты до получения однообразной массы. Затем центрифугировали при 10000 об/мин в течение 20 мин. К 10 мл раствора добавляли 10 капель $0,5 \%$ раствора крахмала и титровали 0,01 н раствором йода в $1 \%$ растворе йодида калия до неисчезающей в течение 10 с окраски.

Содержание аскорбиновой кислоты в исследуемом материале рассчитывали на 1,00 г свежего растительного материала (1 мл 0,01 н раствора йода в йодиде калия окисляет 0,88 мг аскорбиновой кислоты) по формуле 


$$
m=0,88 \cdot V,
$$

где $\mathrm{m}$ - масса аскорбиновой кислоты в 1,00 г свежего растительного материала; $\mathrm{V}$ - объем 0,01н раствора йода в $1 \%$ растворе йодида калия, пошедшего на титрование, мл $[14,15]$.

Содержание белка в зеленых частях растений определяли стандартным методом Брэдфорда. Листья $(0,1000$ г) растирали в 600 мкл 0,1 М фосфатном буфере $\mathrm{pH}=7,6$, затем центрифугировали 20 мин при 7000 об/мин. Содержание белка в образце определяли по градуировочному графику, построенному с использованием стандартного раствора БСА (бычий сывороточный альбумин) с начальной концентрацией 200 мкг/мл. Рабочие растворы готовили методом разбавления. Измерения проводились на спектрофотометре СФ-103 в кювете толщиной 1 см, длина волны 595 нм и определяли содержание белка в неизвестной пробе по градуировочному графику [16].

\section{Обсуждение результатов}

ИК-спектры гуминовых веществ, выделенные из сапропеля, имеют характерный для ГК вид в области от 3500 до $1500 \mathrm{~cm}^{-1}$ (рис. 1) [17].

В составе всех спектров ГВ были идентифицированы следующие пики: в области 3500-3400 см-1 соответствует валентным колебаниям гидроксильных групп - $\mathrm{OH}$, преимущественно связанными межмолекулярными водородными связями. На длинноволновом крыле главной полосы около $3200 \mathrm{~cm}^{-1}$ обнаруживается слабое поглощение. Данный участок спектра имеет вид перегиба и отвечает группам -NH, связанным водородными связями. Полосы при $2900 \mathrm{~cm}^{-1}$ относятся к колебаниям групп С-Н в алифатических фрагментах гуминовых веществ. В области 1700-1720 см-1 гуминовые вещества обладают сильным поглощени-

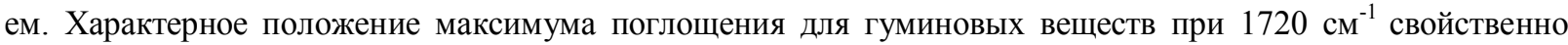
карбонильной группе, которая может быть представлена кетонами, альдегидами и карбоновыми кислотами. Поглощение в области $1650 \mathrm{~cm}^{-1}$ свидетельствует о присутствии карбоксильных групп ароматических и алифатических группировок или повышенного содержания кетонов. Поглощение коротковолновой области спектра (1175-1000 $\mathrm{cm}^{-1}$ ) ответственны валентные колебания спиртовых и углеводных гидроксильных групп. Полоса поглощения при $900 \mathrm{~cm}^{-1}$ характеризуется колебанием ароматических $-\mathrm{CH}_{\mathrm{ap}}$ групп. Таким образом, данные ИК-спектрометрии свидетельствуют о широком спектре функциональных групп, входящих в состав гуминовых веществ сапропеля и отвечающих за их биологическую активность.

Количественное определение функциональных групп определяли, используя методы, описанные в литературе [1, 17]. В таблице 1 представлены результаты определения общей кислотности (Баритовый метод), содержания карбоксильных групп (Са-ацетатный метод) и хинойдных групп.

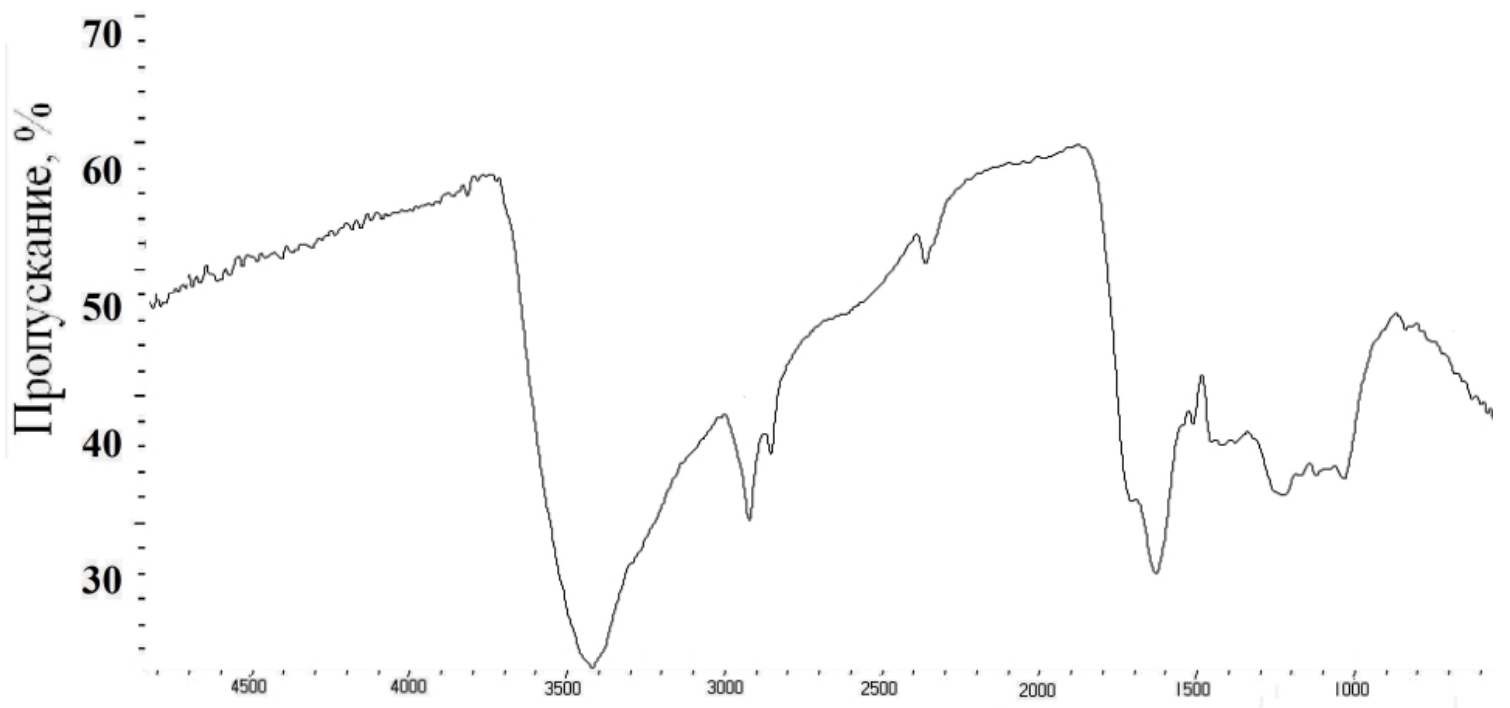

Волновое число, $\mathrm{cm}^{-1}$

Рис. 1. ИК-спектр гуминовых веществ в диапазоне 4500-500 см-1 
Таблица 1. Общее содержание функциональных групп в составе гуминовых веществ

\begin{tabular}{|c|c|c|c|}
\hline $\begin{array}{c}-\mathrm{COOH}+\mathrm{ArOH}, \text { ммоль/Г } \\
\text { Баритовыйметод }\end{array}$ & $\begin{array}{c}\text {-СООН,ммоль/Г } \\
\text { Са-ацетатныйметод }\end{array}$ & $\mathrm{ArOH}^{*}$, ммоль/Г & $\begin{array}{c}\text { Хиноидныегруп- } \\
\text { пы,ммоль/г }\end{array}$ \\
\hline $5 \pm 1$ & $4,0 \pm 0,8$ & $1,0 \pm 0,3$ & $6,2 \pm 0,6$ \\
\hline
\end{tabular}

* - Содержание фенольных групп рассчитывали по разности определений баритовым и Са-ацетатным методами.

Из таблицы 1 видно, что гуминовые вещества, входящие в состав сапропеля, обеднены фенольными гидроксилами, но более окислены, о чем свидетельствует содержание хиноидных и карбоксильных групп. Это связано с тем, что исходный биоматериал, т.е. водоросли, больше подвержен действию микроорганизмов и кислорода воздуха и переводит гидроксильные группы ароматических колец в хиноидные структуры. Наличие хиноидных групп в составе гуминовых веществ обусловливает биологическую активность гуминовых препаратов. Хиноны, обладающие высоким окислительно-восстановительным потенциалом, являются катализаторами окислительно-восстановительных реакций, которые протекают через стадию образования радикалов типа семихинонов.

Наличие хиноидных групп, имеющих парамагнитные свойства, свидетельствует о том, что ГВ могут играть роль «ловушек» для активного радикала. В результате происходит образование нейтральной молекулы и радикала менее активного (ингибирование) или образуется нейтральная молекула и новый более активный радикал, который инициирует радикальный процесс.

Таким образом, на основании полученных данных структурно-группового анализа можно предположить, что гуминовые вещества сапропеля реки Упы Тульской области будут проявлять стимулирующее действие на рост и развитие растений. Выбор томатов F1 сорта Джина агрофирмы «АЭЛИТА» в качестве тесткультур определялся их сельскохозяйственной важностью и биологическими характеристиками. Данный сорт томатов среднеспелый, высокоурожайны, созревает на 100-117 день после появления всходов и не требует пасынкования. Семена томатов контрольной и опытной групп по 20 штук, после предварительной стерилизации в $10 \%$ растворе $\mathrm{NaClO}$, высаживали в почву. Всхожесть семян наступила на третий день после высадки их в почву и составила 100\%.

Биометрические характеристики томатов. Один раз в неделю группа тест-культур томатов в качестве подкормки получала гуминовые вещества сапропеля реки Упы Тульской области, а контрольная удобрение «Идеал». Биометрические характеристики растений (высота растей, ширина и длина листа) контролировали каждые 7 суток в течение 90 дней. Результаты представлены на рисунке 2. В течение всего периода наблюдения томаты контрольной и тестовой групп имели сходный общий прирост биомассы. У растений на всем протя-
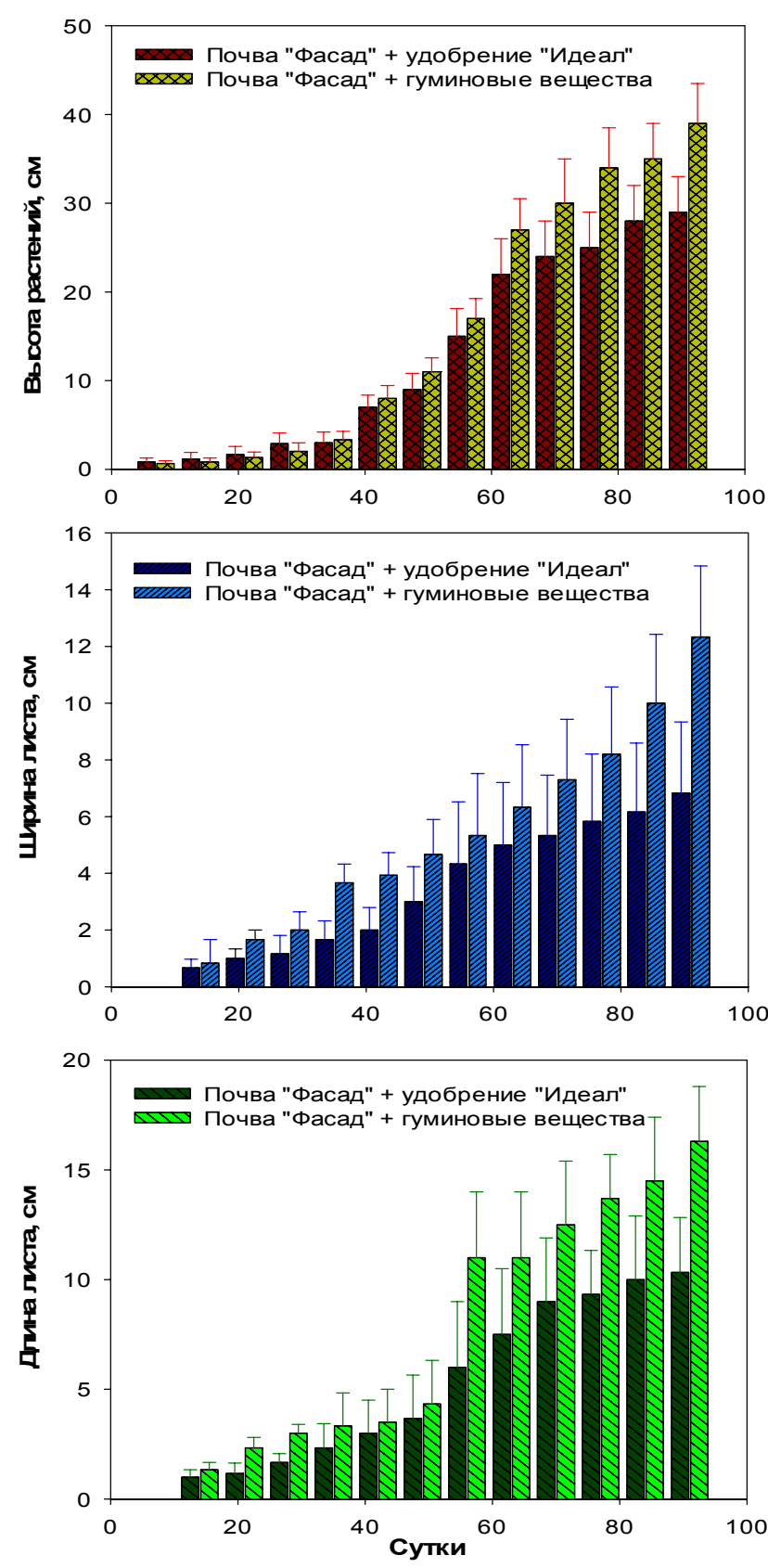

Рис. 2. Биометрические характеристики томатов 
жении роста отмечалась одинаковая длина стебля и настоящего листа, однако у экспериментальных растений ширина листа больше на 70\%.

Таким образом, можно утверждать, что ГВ сапропеля реки Упы Тульской области содержат все необходимые для роста и развития растений компоненты, прежде всего аммонийный азот, входящий в качестве остатков аминокислот водорослей.

Опускаясь на дно бассейна, скопления водорослей гидролизуются с образованием аминокислот и жирных кислот. Жирные кислоты частично полимеризуются до циклических кислот, которые декарбоксилируются до углеводородов. Другая часть жирных кислот переходит в кетоны без полимеризации. Аминокислоты, вступая в реакции поликонденсации, образуют периферическую часть гуминовых веществ. Все превращения водорослей, которые инициируют полимеризацию ненасыщенных жирных кислот, возможны только в присутствии кислорода.

Время наступления фенологических фаз у контрольной и экспериментальных групп растений не различалось. Стадия бутонизации наступила только у 20\% контрольной и $10 \%$ экспериментальной групп растений. Стадии начала плодоношения не достигла ни одна группа. Это связано с малым объемом контейнеров и недостатком питательных веществ. Увядание растений после 112 дней наблюдений не наступило.

Содержание фотосинтетических пигментов в зеленых частях томатов определяли спектрофотометрическим методом. Результаты представлены в таблице 2.

Из таблицы 2 видно, что экспериментальные образцы содержат большее количество пигментов. Это связано с условиями минерального питания. Для образования хлорофилла необходимо достаточное количество железа, при его недостатке листья взрослых растений теряют окраску. Железо участвует на этапе синтеза $\alpha$-аминолевулиновой кислоты из глицерина и сукцинил-КоА, а также синтеза протопорфирина. На синтез хлорофилла влияет и нормальное снабжение растений азотом и магнием, так как оба эти элемента входят в состав хлорофилла. При недостатке меди хлорофилл легко разрушается. Это связано с тем, что медь способствует образованию устойчивых комплексов между хлорофиллом и соответствующими белками. Недостаток необходимых микроэлементов испытывали растения, выращенные в контрольной группе. Растения, получавшие подкормку из гуминовых веществ сапропеля, таким образом, получали весь набор микро- и макроэлементов.

Содержание белка в зеленых частях томатов определяли методом Брэдфорда. Результаты показали, что общее содержание белка (альбуминов и глобулинов) в томатах, выращенных в условиях почвы «Фасад» с добавлением гуминовых веществ, выше на 60\%, чем в контрольной группе, и составляет $180 \pm 30$ мкг/мл. Очевидно, это связано с тем, что подкормка гуминовыми веществами сапропеля содержит большее количество аммонийного азота, доступного для синтеза растениями собственных аминовеществ и далее белков.

Аскорбиновой кислоте принадлежит значительное место в дыхании растений. Наличие аскорбиновой кислоты в растениях и ее участие в дыхательной системе придает большую стойкость растительному организму, так как она может окисляться различными «конечными» оксидазами, т.е. может функционировать в различных условиях температуры и на различных этапах развития растений. Эксперимент показал, что концентрация аскорбиновой кислоты в зеленых частях томатов в экспериментальной и контрольной группе составляет $0,18 \pm 0,06$ и 0,088 $\pm 0,005$ мг/г соответственно. Таким образом, в томатах, выращенных на почве «Фасад» с добавление ГВ сапропеля, концентрация аскорбиновой кислоты на 104\% выше, чем в контрольном образце.

На основании биометрических исследовании и биохимических показателей (содержание фотосинтетичских пигментов, аскорбиновой кислоты и белка) можно рекомендовать гуминовые вещества сапропеля реки Упы Тульской области в качестве основы для создания комплексных удобрений.

Таблица 2. Содержание фотосинтетических пигментов в образцах

\begin{tabular}{l|c|c|c}
\hline \multicolumn{2}{c|}{ Показатель } & Контрольная группа & Экспериментальная группа \\
\hline \multirow{3}{*}{$\mathrm{C}$, мг/л } & Хлорофилл $a$ & $3,6 \pm 0,7$ & $5,7 \pm 0,6$ \\
& Хлорофилл $b$ & $2,2 \pm 0,7$ & $3,7 \pm 0,5$ \\
& Каротиноиды & $1,6 \pm 0,3$ & $2,7 \pm 0,4$ \\
\hline \multirow{2}{*}{$\mathrm{F} \times 10^{-4}$ мг $/ \Gamma$} & Хлорофилл $a$ & $8,9 \pm 0,8$ & $14,2 \pm 0,9$ \\
& Хлорофилл $b$ & $5,4 \pm 0,7$ & $7,6 \pm 0,7$ \\
& Каротиноиды & $3,9 \pm 0,4$ & $5,2 \pm 0,6$ \\
\hline
\end{tabular}




\section{Выводы}

1. В составе гуминовых веществ сапропеля реки Упы Тульской области количественно определено содержание основных функциональных групп (карбоксильные, фенольные и хиноидные), которые определяют их биологическое действие. Обогащенность хиноидными группами $(6,2 \pm 0,6$, ммоль/г), которые обладают окислительно-восстановительными свойствами и являются «ловушками» для активного радикала и влияют на функционирование антиоксидантной системы защиты в клетках растений.

2. Растения, получавшие в качестве подкормки гуминовые вещества сапропеля, отличались большим содержанием фотосинтетичских пигментов, таких как хлорофилл $a$, хлорофилл $b$ и каротиноиды (на 58-69\%), аскорбиновой кислоты (на 104\%) и белка (на 60\%), по сравнению с контрольной группой. Гуминовые вещества, выделенные из сапропеля р. Упы Тульской области, содержат весь набор органических и неорганических веществ, необходимых для выращивания растений томатов, и могут быть использованы для получения удобрений на их основе.

\section{Список литературь}

1. Орлов Д.С., Садовникова Л.К., Суханова Н.И. Химия почв : учебник. М., 2005. 558 с.

2. Перминова И.В., Калмыков С.Н., Карпюк Е.А. Получение алкоксисилильного производного гуминовых веществ для сорбции NP (V) и PU (V) // Вопросы атомной науки и техники. Серия: Материаловедение и новые материалы. 2013. №1. С. 148-158.

3. Dmitrieva E., Efimova E., Siundiukova K., Perelomov L. Surface properties of humic acids from peat and sapropel of increasing transformation // Environmental Chemistry Letters. 2015. Vol. 13. N2. Pp. 197-202.

4. Guetzloff T.F., Rice J.A. Does humic acid form a micelle? // Science of the total environment. 1994. Vol. 152. N1. Pp. 31-35.

5. Terashima M., Fukushima M., Tanaka S. Influence of $\mathrm{pH}$ on the surface activity of humic acid: micelle-like aggregate formation and interfacial adsorption // Colloids and Surfaces A: Physicochemical and Engineering Aspects. 2004. Vol. 247. N1. Pp. 77-83.

6. Perminova I.V., Hatfield K. Remediation chemistry of humic substances: theory and implications for technology // Use of humic substances to remediate polluted environments: from theory to practice. Springer Netherlands, 2005. Pp. 3-36.

7. Perminova I.V., Kovalevsky D.V., Yashchenko N.Yu, Danchenko N.N., Kudryavtsev A.V., Zhilin D.M., Kulikova N.A., Lebedeva G.F., Petrosyan V.S. Humic substances as natural detoxicants // Humic substances and organic matter in soil and water environments: characterization, transformations and interactions. Eds. CE Clapp., MHB Hayes, N. Senesi, S.M. Griffith. 1996. Pp. 399-406.

8. Борисенко В.В., Хусид С.Б., Лысенко Ю.А., Фолиянц Б.В. Биологическая активность гуминового комплекса различного происхождения и его влияние на рост и развитие растений // Политематический сетевой электронный научный журнал Кубанского государственного аграрного университета. 2015. №110. С. 1167-1177.

9. Перминова И.В. Гуминовые вещества - вызов химикам XXI века // Химия и жизнь. 2008. Т. 1. С. 50-55.

10. Дмитриева Е.Д., Горячева А.А., Переломов Л.В., Сюндюкова К.В., Леонтьева М.М. Сорбционная способность гуминовых веществ торфов различного происхождения Тульской области по отношению к ионам $\mathrm{Pb}(\mathrm{II}) / / \mathrm{Vз}-$ вестия Тульского государственного университета. Естественные науки. 2015. №4. С. 205-219.

11. Felbeck G.T. Structural chemistry of soil humic substances // Advances in Agronomy. 1965. Vol. 17. Pp. 327-368.

12. Lichtenthaler H.K., Wellburn A.R. Determinations of total carotenoids and chlorophylls a and b of leaf extracts in different solvents // Biochemical Society Transactions. 1983. Vol. 11. N5. Pp. 591-592.

13. Гавриленко В.Ф., Жигалова Т.В., Ермаков И.П. Большой практикум по фотосинтезу. М., 2003. 256 с.

14. Ballentine R. Determination of ascorbic acid in citrus fruit juices // Industrial \& Engineering Chemistry Analytical Edition. 1941. Vol. 13. N2. Pp. 89-89.

15. Ермаков А.И., Арасимович В.В., Смирнова-Иконникова М.И., Ярош Н.П., Луковникова Г.А. Методы биохимического исследования растений. Л., 1972. С. 88-92.

16. Kruger N.J. The Bradford method for protein quantitation // The protein protocols handbook. 2009. Pp. 17-24.

17. Жилин Д.М., Перминова И.В., Петросян В.С. Исследование взаимодействия гумусовых кислот со ртутью (II) // Экологическая химия. 1996. Т. 5. №2. С. 131-137. 
Dmitrieva E.D. *, Siundiukova K.V., Akatova E.V., Leont'eva M.M., Volkova E.M., Muzafarov E.N. BIOLOGICAL ACTIVITY OF HUMIC SUBSTANCES SAPROPEL UPA RIVER TULA REGION

\section{Tula State University, pr. Lenina, 92, Tula, 300012 (Russia),e-mail: Dmitrieva_ed@rambler.ru}

The influence of natural polymers - humic substances (HS) from sapropel of the river Upa of the Tula region on the growth and development of the grade of F1 tomato Gina of agricultural company "Aelita", was considered in this paper. The content of the main functional groups (carboxyl, phenolic and quinoid), that define the biological effect of HS were quantitative determined in the composition of HS. Saturation of quinoid groups that possess redox properties and are "trapped" active radical and affect on the operation of antioxidant defense system in plants cells was proved. Stimulating effect of the analyzed humic preparations on the growth of the experimental plants was detected:increase of the total biomass and biometric data (length and width of the sheet, the height of the plants), elevation of amounts of the photosynthetic pigments, proteins and ascorbic acid. Plants that have been treated as fertilizing by humic substances from sapropel were distinguished by high content of photosynthetic pigments such as chlorophyll a, chlorophyll b, and carotenoids (58-69\%), ascorbic acid (104\%) and protein (60\%) compared with control group. Humic substances contain the entire set of organic and inorganic substances required for the cultivation of tomato plants.

Keywords: humic substances, biological activity, photosynthetic pigments, ascorbic acid.

\section{References}

1. Orlov D.S., Sadovnikova L.K., Sukhanova N.I. Khimiia pochv: uchebnik. [Soil chemistry: textbook]. Moscow, 2005, 558 p. (in Russ.).

2. Perminova I.V., Kalmykov S.N., Karpiuk E.A. Voprosy atomnoi nauki i tekhniki. Seriia: Materialovedenie i novye materialy. 2013, no. 1, pp. 148-158. (in Russ.).

3. Dmitrieva E., Efimova E., Siundiukova K., Perelomov L. Environmental Chemistry Letters, 2015, vol. 13, no. 2, pp. 197-202.

4. Guetzloff T.F., Rice J.A. Science of the total environment, 1994, vol. 152, no. 1, pp. 31-35.

5. Terashima M., Fukushima M., Tanaka S. Colloids and Surfaces A: Physicochemical and Engineering Aspects, 2004, vol. 247, no. 1, pp. 77-83.

6. Perminova I.V., Hatfield K. Use of humic substances to remediate polluted environments: from theory to practice, Springer Netherlands, 2005, pp. 3-36.

7. Perminova I.V., Kovalevsky D.V., Yashchenko N.Yu, Danchenko N.N., Kudryavtsev A.V., Zhilin D.M., Kulikova N.A., Lebedeva G.F., Petrosyan V.S. Humic substances and organic matter in soil and water environments: characterization, transformations and interactions, eds. CE Clapp., MHB Hayes, N. Senesi, S.M. Griffith, 1996, pp. 399-406.

8. Borisenko V.V., Khusid S.B., Lysenko Iu.A., Foliiants B.V. Politematicheskii setevoi elektronnyi nauchnyi zhurnal Kubanskogo gosudarstvennogo agrarnogo universiteta, 2015, no. 110, pp. 1167-1177. (in Russ.).

9. Perminova I.V. Khimiia i zhizn', 2008, vol. 1, pp. 50-55. (in Russ.).

10. Dmitrieva E.D. Goriacheva A.A., Perelomov L.V., Siundiukova K.V., Leont'eva M.M. Izvestiia Tul'skogo gosudarstvennogo universiteta. Estestvennye nauki, 2015, no. 4, pp. 205-219. (in Russ.).

11. Felbeck G.T. Advances in Agronomy, 1965, vol. 17, pp. 327-368.

12. Lichtenthaler H.K., Wellburn A.R. Biochemical Society Transactions, 1983, vol. 11, no. 5, pp. 591-592.

13. Gavrilenko V.F., Zhigalova T.V., Ermakov I.P. Bol'shoi praktikum po fotosintezu. [Large workshop in photosynthesis]. Moscow, 2003, 256 p. (in Russ.).

14. Ballentine R. Industrial \& Engineering Chemistry Analytical Edition, 1941, vol. 13, no. 2, pp. 89-89.

15. Ermakov A.I., Arasimovich V.V., Smirnova-Ikonnikova M.I., Iarosh N.P., Lukovnikova G.A. Metody biokhimicheskogo issledovaniia rastenii. [Methods of Biochemical Plant Research]. Leningrad, 1972, pp. 88-92. (in Russ.).

16. Kruger N.J. The protein protocols handbook, 2009, pp. 17-24.

17. Zhilin D.M., Perminova I.V., Petrosian V.S. Ekologicheskaia khimiia, 1996, vol. 5, no. 2, pp. 131-137. (in Russ.).

Received July 22, 2016

Revised October 27, 2016

\footnotetext{
* Corresponding author.
} 